\title{
Development of Problem-Based Termodynamics Learning Devices to Improve Concept Understanding and Critical Thinking Ability
}

\author{
A. Harjono ${ }^{1,2, *}$ \\ ${ }^{1}$ Master of Science Education Study Program, University of \\ Mataram, West Nusa Tenggara, Indonesia \\ ${ }^{2}$ Physics Education Program, University of Mataram, West \\ Nusa Tenggara, Indonesia \\ *harjonofkip@unram.ac.id
}

\author{
Aris Doyan ${ }^{1,2}$, Susilawati $^{1,2}$, Hamidi $^{1}$ \\ ${ }^{1}$ Master of Science Education Study Program, University \\ of Mataram, West Nusa Tenggara, Indonesia \\ ${ }^{2}$ Physics Education Program, University of Mataram, West \\ Nusa Tenggara, Indonesia \\ aris_doyan@unram.ac.id
}

\begin{abstract}
This study aims to develop problem-based learning tools to improve students' conceptual understanding and critical thinking skills. The development model will be carried out through the define, design, development and disseminate stages. The learning tools developed in this study are in the form of a syllabus, Semester Program Plan, Student Work Sheets and instruments for understanding concepts and critical thinking skills. The results of the developed learning tools are valid with an average value of 88.13 with a very decent category, and understanding the concept of each sub-material has an increase seen in the highest $\mathbf{N}$-Gain value in the entropy sub-material with a value of 0.79 in the high category. Meanwhile, the ability to think critically using the PRISCO indicator shows an increase in each indicator and the highest N-Gain value on the Inference and Clarity indicators with a value of 0.75 and 0.76 . From the inference and clarity indicators, students can make conclusions and explain again the thermodynamic material that has been taught.
\end{abstract}

Keywords-problem-based learning, discovery learning, scientific approach, understanding concept, science process skills

\section{INTRODUCTION}

Thermodynamics is one of the branches of physics which is applied in everyday life. Thermodynamics describes the attempt to convert heat into energy and its supporting properties. Thermodynamics is closely related to the physics of energy, heat, work, entropy and process spontaneity.

In addition, Thermodynamics also deals with static mechanics. This branch of physics studies an exchange of energy in the form of heat and work, limiting systems and the environment. Applications and applications of Thermodynamics can occur in the human body, the events of blowing hot coffee, electronic tools, refrigerators, cars, power plants and industry, are the thermodynamic events that are closest to everyday life.

Thermodynamics is one of the compulsory subjects that students majoring in physics education at the University of Mataram must take. Thermodynamics lectures will run smoothly if planning is well done as needed.
The gaps that occur in thermodynamics learning students do not understand basic physics concepts physically and mathematically.

The good quality of lectures is achieved when good learning tools are available. Improving the quality of learning for a lecturer is very strategic, because it functions as the spearhead of the change from not being able to become able, from not being able to master it to mastering, from not understanding to understanding [1]. Student factors, available facilities, tools and media, as well as environmental factors can also influence the learning process [2].

One learning model that provides opportunities for students to understand the concept of physics is the Problem Based Learning model which encourages educators to connect the material being taught with the real world situation of students and also encourages students to make connections between their knowledge and its application in their daily life.

This model is a learning approach in which students work on authentic problems with the intention of compiling their own knowledge, developing inquiry and higher-order thinking skills, developing independence, and self-confidence. In this model, the role of the teacher is to ask problems, ask questions, facilitate an atmosphere of discussion, provide research facilities and conduct research. This learning model also involves many students actively in the learning process [3].

Seeing this fact, it is necessary to develop learning tools by implementing problem-based learning model Problem Based Learning which is an effort to improve students' conceptual understanding and critical thinking in thermodynamics subjects. Because the real form of lecturer preparation is to make learning tools before carrying out lecture activities, later learning can be used as a guide for lecturers to achieve learning goals, namely increasing the results of understanding concepts and students' critical thinking skills, especially in thermodynamics subjects [4]. 
Thermodynamic material described for conceptual understanding consists of five sub-materials, namely Properties of Pure Substance, First Law of Thermodynamics and Energy Equation, Energy Analysis for a Control Volume, The Second Law of Thermodynamics, Entropy [5].

There are six basic elements in critical thinking skills, abbreviated as FRISCO, namely F (Focus), to make a decision about what is believed, one must be able to clarify certain questions or issues. $\mathrm{R}$ (Reason), knowing the reasons that support or conflict with the situation and relevant facts. I (Inference), making a reasoned conclusion or presenting. An important part of this concluding step is identifying assumptions and seeking solutions, considering the situation and evidence. S (Situation), understand the situation and always keep the situation in mind. $\mathrm{C}$ (Clarity), explains the meaning or terms used. O (Overview), step back and thoroughly examine the decision taken [6-8]

In connection with the above, the authors are interested in conducting research on the Development of Problem Based Thermodynamics Learning Tools to Improve Learning Outcomes and Concept Understanding.

\section{MethodS}

This research was conducted on physics education students class of 2018. The number of students who participated in 32 people. The sampling technique used is the total sampling technique.

The type of research is development research, which produces certain products, and tests the effectiveness of these products. The steps for developing the 4D model are as follows: Define consists of analyzing the problem, students, concepts, and formulation of learning objectives. Design consists of formulating the objectives of developing real learning media and the initial design of physics learning tools. Development to improve initial drafts of learning tools through expert feedback and revisions. This aims to determine the effectiveness of learning tools that have been refined based on input from experts. disseminate is disseminating problem-based thermodynamic learning tools [9].

Learning tools that have been developed are carried out due validation, effectively and efficiently in improving students' conceptual understanding and critical thinking skills [10].

The validation data obtained were then analyzed using the percentage of components based on the Likert scale in Table 1.

TABLE I. SCORING QUESTIONNAIRE INSTRUMENTS

\begin{tabular}{|l|l|}
\hline \multicolumn{1}{|c|}{ Answer } & \multicolumn{1}{c|}{ Score } \\
\hline Very Good & 5 \\
\hline Good & 4 \\
\hline Enough & 3 \\
\hline Less & 2 \\
\hline Very Less & 1 \\
\hline
\end{tabular}

Furthermore, the validation score is calculated using the following equation.

$$
P_{(k)}=\frac{S}{N} \times 100 \%
$$

Where:

$\mathrm{P}_{(\mathrm{k})}=$ Percentage of components

$\mathrm{S}=$ The total score of the research results component

$\mathrm{N}$ = Maximum number of scores

The percentages that have been obtained are then transformed into intervals as in Table 2.

TABLE II. PERCENTAge RANGES AND QuAlitative CRITERIA

\begin{tabular}{|l|l|}
\hline \multicolumn{1}{|c|}{ Percentage } & \multicolumn{1}{c|}{ Criteria } \\
\hline $85-100 \%$ & Very Good \\
\hline $69-84 \%$ & Good \\
\hline $53-68 \%$ & Enough \\
\hline $37-52 \%$ & Less \\
\hline $20-36 \%$ & Very Less \\
\hline
\end{tabular}

To see the increase in students' understanding of science process concepts and skills, the $\mathrm{N}$-Gain equation is used as follows.

$$
\mathrm{N} \text {-gain }=\frac{\text { Spost }- \text { Spre }}{\text { Smax }- \text { Spre }} \times 100 \%
$$

The criteria for the N-Gain score can be seen in Table 3 .

TABLE III. CRITERIA FOR GAIN SCORE

\begin{tabular}{ll}
\hline \multicolumn{1}{c}{ Classification } & \multicolumn{1}{c}{ Category } \\
\hline $\mathbf{0 . 7}<\boldsymbol{g} \leq \mathbf{1 . 0}$ & High \\
$\mathbf{0 . 3}<\boldsymbol{g} \leq \mathbf{0 . 7}$ & Middle \\
$\boldsymbol{g} \leq \mathbf{0 , 3}$ & Low \\
\hline
\end{tabular}

\section{RESUlTS AND DISCUSSION}

The data obtained in this study were the results of the validation of the learning tools and the results of the evaluation of conceptual understanding and critical thinking skills for thermodynamic material. For the results of the evaluation of conceptual understanding and critical thinking skills, two tests were carried out, namely a pre-test which was carried out before students took part in the learning and post-tests after the students attended the learning.

The results of the analysis of the device validity test can be seen in Table 4.

TABLE IV. THE RESULTS OF THE LEARNING DEVICE VALIDITY TEST

\begin{tabular}{|l|l|l|l|}
\hline No. & \multicolumn{1}{|c|}{ Aspects assessed (\%) } & Values (\%) & Description \\
\hline 1. & Syllabus & 87.22 & Very Appropriate \\
\hline 2. & Lesson Plan & 86.34 & Very Appropriate \\
\hline 3. & Worksheet Mastery & 88.56 & Very Appropriate \\
\hline 4. & $\begin{array}{l}\text { Concept } \\
\text { Assessment }\end{array}$ & 89.55 & Very Appropriate \\
\hline 5. & $\begin{array}{l}\text { Instrument for Assessment } \\
\text { of critical thinking skills }\end{array}$ & 88.98 & Very Appropriate \\
\hline \multicolumn{2}{|l|}{ Average } & 88.13 & Very Appropriate \\
\hline
\end{tabular}

Based on Table 4 above, it can be seen that the learning device developed after being validated by an expert validator gets the predicate very suitable for use. This means that this 
learning tool can be used in learning if the indicators and learning objectives have consistency to be achieved, if it is based on a strong theory and has consistency with the learning objectives to be achieved [11].

Learning tools that have been developed are then used in learning with the aim of measuring students' understanding of concepts and critical thinking skills. The benchmarks for measuring the effectiveness of this learning device are by looking at changes in the pretest and posttest scores on the two components of conceptual understanding and critical thinking skills.

Test the effectiveness of the problem-based learning model using the conceptual understanding test and critical thinking skills. The results of the concept understanding test can be seen in Figure 1.

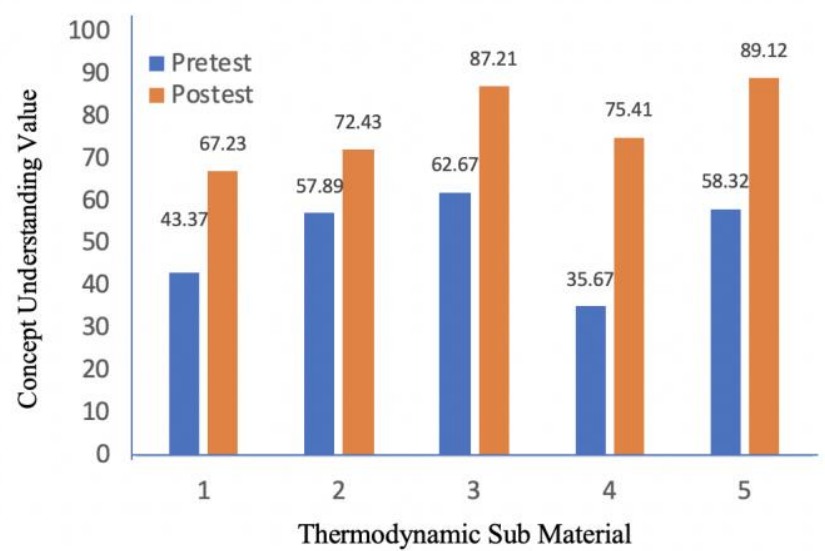

Fig. 1. Graph of the mean value of the pre-test and post-test understanding of the concept of some thermodynamic sub-material.

In Figure 1, it can be seen that the value of mastery of the concept of each thermodynamic sub-material obtained by the post-test score is higher than the pretest. From the data, it can be seen that the student's mastery of the concept is the highest in the Entropy sub-material. In the entropy material during learning, it seems very enthusiastic about linking the energy correlation with temperature changes and solving related problems. These results indicate that the problem-based learning model improves the conceptual understanding of prospective teacher students.

The increase in mastery of this concept is also evidenced by the results of calculations using the $\mathrm{N}$-Gain equation as shown in the N-Gain graph which can be seen in Figure 2.

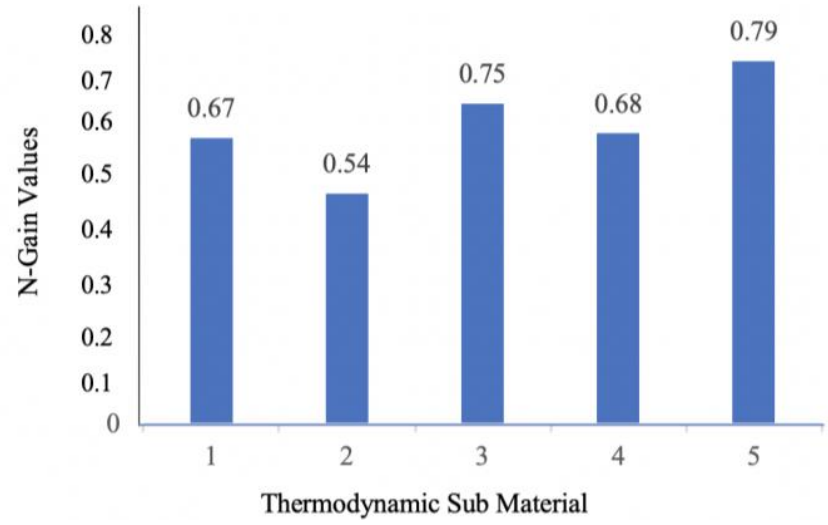

Fig. 2. Graph of the N-Gain Value for Understanding the concept.

Where :

1. Properties of Pure Substance

2. First Law of Thermodynamics and Energy Equation

3. Energy Analysis for a Control Volume

4. The Second Law of Thermodynamics

5. Entropy

In Figure 2 it can be seen that the N-Gain value in the entropy sub-material and Energy Analysis for a Control Volume has a high value that is 0.79 and 0.75 . This high value can be seen from the more critical responses of students in learning $[12,13]$.

The effectiveness test can be continued by looking at the improvement of students' critical thinking skills in thermodynamic material as shown in Figure 3.

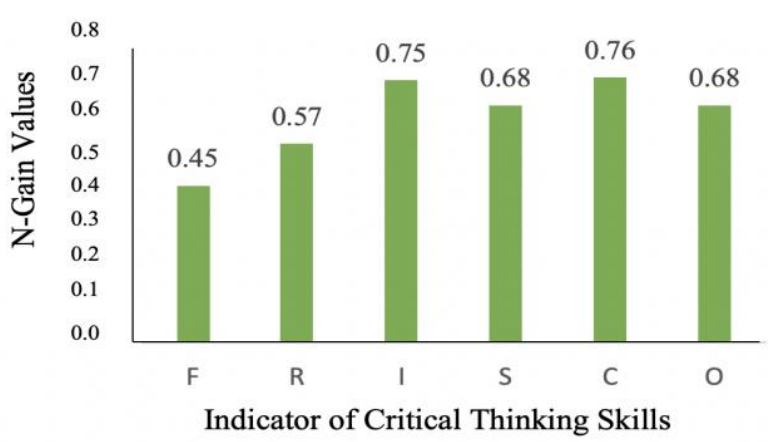

Fig. 3. N-Gain value of the student's critical thinking ability indicator.

From Figure 3, it can be seen that the N-Gain value of the student's critical thinking ability indicator is in the medium and high categories. High indicators are found in the Inference and Overview with values 0.75 and 0.76 , where students after learning can summarize again from the submaterial of thermodynamics and move to practice solving more difficult questions for post-test preparation $[14,15]$.

\section{CONCLUSIONS}

The conclusion that can be drawn based on the purpose of the research carried out is that The results of the developed learning tools are valid with an average value of 88.13 with a very decent category, and understanding the concept of each sub-material has an increase seen in the highest N-Gain value in the entropy submaterial with a value of 0.79 in the high category. Meanwhile, 
the ability to think critically using the PRISCO indicator shows an increase in each indicator and the highest $\mathrm{N}$-Gain value on the Inference and Clarity indicators with a value of 0.75 and 0.76 . the thermodynamic learning device developed with a problembased learning model is effective in increasing concept understanding and critical thinking skills of prospective teacher students.

\section{ACKNOWLEDGMENT}

Thanks to the research team, to the head of the Mataram University Physics Education study program, to the Mataram University PNBP research funders who have facilitated the implementation of this research to completion and all parties who have helped in this research.

\section{REFERENCES}

[1] Rusman. "Model-Model Pembelajaran Mengembangkan Profesionalisme Guru Edisi Kedua”. Jakarta: Rajawali Pers. 2014.

[2] H. E. Mulyasa, "Pengembangan dan Implementasi Kurikulum 2013", Bandung: Remaja Rosdakarya. 2014.

[3] Y. Abidin, "Desain Pembelajaran dalam Konteks Kurikulum 2013", Bandung. PT Refika Aditama. 2014.

[4] A. Doyan, I. K. Y. Sukmantara, Pengembangan Web Internet Fisika untuk Meningkatkan penguasaan Konsep dan Kemampuan pemecahan Masalah Siswa SMK. “Jurnal Pendidikan Fisika Indonesia”, 10(2) pp 117-127. 2014.

[5] K. Jamuri, A. Doyan, Pengaruh Model Pembelajaran Kooperatif Stad Berbasis Multi Media Interaktif Terhadap Penguasaan Konsep Siswa Pada
Materi Termodinamika, "Jurnal Penelitian Pendidikan IPA", 1(1) pp 123134, 2015.

[6] R.H. Ennis, "Critical Thinking”. USA: Prentice-Hall, Inc. 1996

[7] R.H. Ennis, "Is Critical Thinking Culturally Biased? Teaching Philosophy”, 21, 1 (March), 15- 33. 1998.

[8] R.H. Ennis, The Nature of Critical Thinking: An Outline of Critical Thinking Dispositions and Abilities. The Sixth International Conference on Thinking at MIT. Cambridge. 2011.

[9] Purwanto. "Evaluasi Hasil Belajar". Yogyakarta: Pustaka Pelajar. 2013.

[10] S. Arikunto, "Prosedur Penelitian Suatu Praktek". Jakarta: Rineka Cipta. 2013.

[11] L.S. Handriani, A. Harjono, A. Doyan, Pengaruh Model Pembelajaran Inkuiri Terstruktur Dengan Pendekatan Saintifik Terhadap Kemampuan Berpikir Kritis Dan Hasil Belajar Fisika Siswa, "Jurnal Pendidikan Fisika dan Teknologi”, 1(3) pp 210-220. 2015.

[12] A. Doyan, A.W. Jufri, Susilawati, A. Hardiyansyah, K. Auliya, S. Hakim, L. Muliyadi, Development of Learning Media of Microscope Portable Auto Design to Increase Student's Problem- Solving Ability in Light and Optical Tools Topic, "Advances in Social Science, Education and Humanities Research, Atlantis Press”, (438) pp 300-302. 2020.

[13] M.T.S. Pramudyawan, A. Doyan, J. Ardhuha, Pengaruh Model Pembelajaran Inkuiri Terbimbing Berbantuan Kit Alat Percobaan Usaha dan Energi terhadap Penguasaan Konsep Fisika Peserta didik, "Jurnal Penelitian Pendidikan IPA", 6(1) pp 40-44, 2020.

[14] L.G. Snyder and M.J. Snyder, Teaching Critical Thinking and Problem Solving Skills. "The Delta Pi Epsilon Journal". Vol. L, No. 2, Spring/Summer, pp 90-99. 2008.

[15] S. Aminah, A. Doyan, Hikmawati, Pengaruh Model Pembelajaran Quantum dengan Bantuan Simulasi PHET Terhadap Kemampuan Berpikir Kritis Peserta Didik, "PIJAR MIPA", 15 (3), 293-397, 2020. 